\title{
Governance of Resources, Processes, Outputs and Performance Measurement of Mosques based on Maqasid Al-Syariah
}

Muhd Fauzi Bin Abd Rahman', Mursal Salam², Sharifah Norzehan Syed Yusuf ${ }^{3 *}$, Nor'azam Mastuki ${ }^{4}$, Norziana Lokman ${ }^{5}$, Nathrah Yaacob ${ }^{1}$, Siti Mariam Melissa Abdullah ${ }^{1}$

${ }^{1}$ INTI International College Subang, Malaysia

${ }^{2}$ Redesign Primanusa Consulting, Jogjakarta, Indonesia

${ }^{3}$ Accounting Research Institute, Universiti Teknologi MARA, Malaysia

${ }^{4}$ Faculty of Accountancy, Universiti Teknologi MARA, Malaysia

${ }^{5}$ Faculty of Administrative Science and Policy Studies, Universiti Teknologi MARA, Malaysia

\section{ABSTRACT}

Based on Maqasid Al-Syariah the purpose of this study was to examine the relationship between the four traditional performance measurement variables: resources, processes, outputs, and outcomes to establish a viable performance measurement framework for mosques. The second was to include governance as the fifth variable as part of the performance measurement framework. This study employed a quantitative research method using self-administered questionnaires as the primary form of data collection. A total of 800 questionnaires were distributed, and only 224 questionnaires were received. From that, 210 questionnaires were analysed using Structural Equation Modeling (SEM). Three main findings were obtained. First, the finding found that processes played a significant role in mediating the influence of resources on outputs. Second, the Maqasid Syariah Index had a significant negative association with outputs which indicated that as outputs increase, the objectives of the mosques generally diminish. Therefore, mosques are not able to meet their goals with increased outputs. Third, governance directly affects the resources and outputs of mosques. The governance mechanisms through the application of accountability, disclosure and transparency dimensions directly affected mosque resources. The results of this study provide value to stakeholders of mosques specifically those who are direct recipients of the mosque operations and activities, such as the religious authorities and society.

Keywords - Governance, Maqasid Syariah Index, Outputs, Performance Measurement, Processes, Resources.

ARTICLE INFO

\section{Article History:}

Received: 01 August 2021

Accepted: 25 August 2021

Available online: 31 August 2021

\footnotetext{
• Corresponding Author: Associate Prof. Dr. Sharifah Norzehan Syed Yusuf, shari893@uitm.edu.my, +60192769902, Accounting Research Institute, Level 12 Menara SAAS, Universiti Teknologi MARA, Shah Alam 40450, Malaysia.
} 


\section{INTRODUCTION}

A mosque is a religious non-profit organisaation (NPO) that functions as a venue for congregational and religious activities for Muslims. Nowadays, mosques are found to have lesser worshippers, signified by the lesser number of rows of people performing congregation prayers (Mohd Asri, 2007). Mosques too are used as charity and welfare centres, nursing and medical outlets and a place for some leisure activities (Omer, 2010). In Malaysia, religious programs and activities are carried out in mosques to instil and strengthen Islamic values among members of a community (Mohamed Adil et al., 2013, Abd Rahman et al., 2015). Worshippers would normally attend religious lessons which are held between the sunset or Maghrib and night or Isya prayers (Abd Rahman et al., 2016). Most mosques would appear to be quite empty during daytime due to lack of programs and activities conducted (Abd Rahman et al., 2016).

In this context, the State Islamic Religious authorities such as Jabatan Agama Islam Selangor (JAIS) has taken some measure to ensure there is no further drop in the number of worshippers attending congregation prayers. Mosques are now aggressively promoting activites to 'enliven' the mosque known as imarah masjid. One of the steps taken by JAIS to implement imarah masjid is to encourage the mosque management to conduct as many religious activities as possible to reach out to all Muslims regardless of age. Hence the performance of the management team at mosques is closely monitored by JAIS to ensure that the administration of these institutions are effective and efficient aside from just providing information about the imarah masjid programs (MAIS News, 2012). The objective is for the management to show improved performance and that they are on track in achieving the goals set.

The issue of performance measurement in mosques has not been accorded due recognition and attention among researchers and as such mosque authorities have started propagating the concept of imarah masjid (Mustari and Jasmi, 2008). Although many studies have been conducted on issues faced by non-profit organisations (NPOs) on performance measurement (Moxham, 2009), there seems to be a lack of literature on issues related to governance and performance applicable to religious- based organisations, including mosques (Said et al, 2013). So far, traditional 
performance measurement of NPOs have focused mostly on constructs such as inputs, processes, outputs and outcomes to evaluate their efficiency and effectiveness (DeGroff et al, 2010) and also, ineffective strategies in sourcing out alternative income (Alim and Abdullah, 2010). Performance measurement is an issue that has garnered the interest amongst NPOs, but religious-based organisation has been slow to latch into such issues, thus impeding their understanding of factors influencing mosque performance (Abd Rahman et al., 2016). In addition, there are also governance issues pertaining to management of mosques such as the lack of accountability in accounting systems, inaccurate recording and reporting of income (Sanusi et al, 2015). Hence, the research objectives of this study were two-fold. First is to determine the relationship between the four traditional performance measurement variables: resources, processes, outputs and outcomes in an effort to establish a viable performance measurement framework for mosques (Abd Rahman et al., 2016). Second, was to include governance as the fifth variable as part of the performance measurement framework. In line with the nature of mosque as an Islamic religious institution, the Maqasid al-Syariah Theory and the Maqasid Syariah Index as proposed by Mohammed et al. (2008) were used in this study.

\section{LITERATURE REVIEW}

The Quran says that, "The mosques of Allah shall be maintained only by those who believe in Allah and the Last Day" (Quran9:18) also provide a valuable reminder in managing places of worship. Mosque officials and committee teams responsible for the administration and maintenance of the mosques should be selected among those who are pious and have the attributes of Taqwa or God consciousness imbued among them. This is to ensure that the sanctity of Islam is protected at all times by those who have been appointed as representatives or keepers of the house of Allah (swt).

\section{Governance from the Islamic Perspective}

The advent of Islam has also been accompanied with a growing concern and need to analyse and develop corporate governance from an Islamic viewpoint, with special reference to the important principles endorsed by the Organisation of Economic Co-operation and Development 
(OECD) ministers in 1999 (Abu-Tapanjeh, 2009). Once these corporate governance principles were embraced by the 30 strong nations of the OECD, they emerged as the preferred reference tool for policy makers, corporations, institutional and regulatory frameworks, and others. There are two OECD principles which are of particular interest to this study which are; Principle 5 on disclosure and transparency and Principle 6 on the responsibilities of the board, that are in line with Islamic teachings. In Islam, accountability requires a true and fair disclosure and transparency. According to Abu-Tapanjeh (2009, p.563), "Accountability is first of all to Allah (swt). The fundamental concept of Islamic accountability is that all resources are made available to individuals in a form of trust. The concept explains that true disclosure of financial facts and accurate information should be made freely available to the users" or stakeholders for that matter. With regard to finance and accounts, Islam advocates fair and just financial transactions for everyone involved, with emphasis on the necessity to record all transactions, bearing in mind that the ultimate accountability is to Allah (swt). Muslims believe that they are answerable to Allah, and all their good deeds or misdeeds in this world, are recorded, documented, and kept. This idea of accountability extends into the business context, where both the management and the providers of capital are accountable for their actions whether within or outside their firms (Yasmin and Haniffa, 2017). From an Islamic standpoint, it can be surmised that Muslims are also held accountable to society in all aspects where they interact. Thus, they are subject to the Syariah or Islamic law and this is all-encompassing across their daily life and practices. This includes practices in their personal or working lives, worship, manners and morals, along with commercial transactions and business practices (Mohamed et al., 2014).

NPOs especially religious-based institutions, have long played key roles in society but, misuse of power in terms of poor management practices and abuse of funds have put the administration and answerability of these organisations into question (Afifuddin and Siti-Nabiha, 2010). In ensuring good governance of a mosque, Borhan et al., (2011) suggested that the organization should be led by a chairman, secretary and treasurer, and the details of their duties are to be made transparent and available to stakeholders. Prior research suggests there are untoward financial management practices in mosques, for example the misappropriation of donated funds (Mohamed et al., 2014; Said et al., 2013). Factors such 
as the absence of internal control procedures may have also led to the mismanagement of financial resources. This is supported by Sanusi et al., (2015) who found that an internal control system plays an important role in ensuring the effectiveness of financial management practices. In order to maintain the image and credibility of mosque committees, an organized financial system is therefore vital, such as having complete income and expenditure statement, clean receipt and payment voucher as well as a sensible financial balance (Abdullah \& Aini, 2017).

\section{Resources, Processes and Resource-Based View Theory}

The Quran $(2: 22,2: 29)$ has described resources as everything that is tangible or otherwise that can be used to help mankind. However, from an academic perspective, the definition of resources has to be more specific in nature (Galbreath, 2005). Resources can be defined as factors which enable a firm to initially function, without them, the business would not be able to develop (Burvill et al., 2018).

Factors here includes finance, human capital, management, expertise, contacts, open innovation, customers and software. Notably, research on firm resources form the basis of the Resource-based View (RBV) Theory are inextricably linked to the performance of firms (Wernerfelt, 1984; Barney, 1991). The RBV became popular when Wernerfelt (1984) suggested in "A Resourced-based View of the Firm" that a firm's success is greatly calculated according to the assets it owns and controls. When an organization possesses and controls specific "strategic resources", it enables the organisation to have a sustained competitive advantage. These valuable, rare, inimitable and non-substitutable (VRIN) strategic resources are considered as not only precious and unmatched, but also possess exceptional characteristics in that they are not duplicable (Barney, 1991) or such resources are resistant to competitor duplication, and mostly intangible in nature (Amit and Schoemaker, 1993). Conversely, Warnier et al., (2013) pointed out that the value of other types of resources beside VRIN resources also contribute significantly to firm performance. Specifically, in their recent study which highlighted the idea that "ordinary resources" may make a significant contribution to performance if coupled with a suitable business model. While a majority of an organisation's assets normally comprise of ordinary resources that are readily available and needed for production processes, 
these resources do not bring any competitive advantages. Without them, however, the organisation may incur more costs and experience less value (Warnier et al., 2013). In another study, Nason and Wiklund (2018) found that other "versatile" resources are associated with higher levels of growth, whereas VRIN resources are not. In this study, mosque officials, committee members, financial resources and mosque facilities are described as the primary resources in mosques (Abd Rahman et al., 2016).

Scholars have been disputing over the predictive power of the Resource Base View Theory (RBV) and have highlighted the role played by managers as catalysts to firm competitive advantage and performance (Sirmon et al., 2007). As expounded by Sirmon et al., (2007), the Resource Management Process Framework demands for managers' ability to acquire, accumulate, and divest (if necessary) resources so that their resource portfolio is both impressive and effective. In essence, managers' skills in managing resources to enhance capabilities and efficacy are seen as a key factor. The RBV theory, cannot therefore, singularly account for firm competitive advantage and management actions in converting firm resources must be considered. A mosque for example, must use and deploy these resources that have the potential to become valuable assets. The mosque management team must have the ability to identify the valuable resources under the organisation's control and the way these resources can compel better performance. Therefore, processes are activities generated by programs in the mosques which transform resources into outputs (Abd Rahman et al., 2016).

\section{Outputs, Outcomes and Performance Measurement}

The terms efficiency and effectiveness are sometimes used in the context whereby effectiveness refers to the extent to which an organisation's objectives and customer requirements are met (outcomes), while efficiency is a measure of how economically the organisation's resources (inputs) are utilized in generating the maximum desired outputs from given inputs and available technology (Abd Rahman et al., 2016). Outputs refer to the completed products of internal activity (processes): the amount of work done by an organisation. Sillanpaa's (2011) adaptation of a similar framework for a study on the primary determiners of performance in Finnish welfare service organisations looked at the horizontal flow of resources, processes, outputs, and outcomes. However, adopting a mainstream framework for 
the performance measurement of mosques may not be entirely suitable for mosques specifically with reference to the outcome measures since mosques have several objectives which may not be easily measurable (Arshad et al, 2018).

Following the previous study by Abd Rahman et al., (2016), this study adapted the performance measurement framework which identifies the ideal objectives of mosques from the Maqasid al-Syariah theory or the objectives of Islamic law (Noordin et al., 2017; Mohammed et al., 2008). The Maqasid Syariah Index developed for the measurement of performance in this study was a measure of the three objectives of mosques which are preserving faith, preserving intellect and public interest. It was proposed that the Maqasid Syariah Index will be used as a proxy measure of the objectives of mosques' (Abd Rahman et al., 2016). The governance variable was also included in the conceptual framework which was expected to have a direct influence on resources and outputs. The conceptual framework is shown in Figure 1 in the next section. In the following sections, 'performance' was used here as the overriding concept which include outputs and outcomes (Wholey, 1996). Hence, performance was used interchangeable either with outputs or outcomes.

\section{CONCEPTUAL FRAMEWORK AND HYPOTHESES DEVELOPMENT}

The conceptual framework is shown in Figure 1. First, this study examined the direct impact of resources on outputs of mosques based on the extended RBV theory (Warnier et al., 2013). Their extended RBV theory introduced alongside strategic resources the concepts of ordinary resources, showing how these resources can contribute to performance. Secondly, this study examined the role of processes in mediating the relationship between resources and outputs of mosques using the resource management process framework (Abd Rahman et al., 2016 as cited in Sirmon et al,. 2007). Thirdly, it examined the relationship between the horizontal flow of inputs, processes, outputs, and outcomes measures based on Sillanpaa's (2011) performance measurement framework. Fourth, the Maqasid al-Syariah theory which forms the basis of the Maqasid Syariah Index as proposed by Mohammed et al. (2008) was used to measure whether the outcomes 
or objectives of mosques are attained. Finally, this study examined if the possibilities of governance factors (such as accountability, disclosure and transparency) had a significant influence on the resources and outputs of mosques respectively. These relationships are based on a study conducted by Abu-Tapanjeh (2009) who analysed and developed corporate governance from the Islamic perspective.

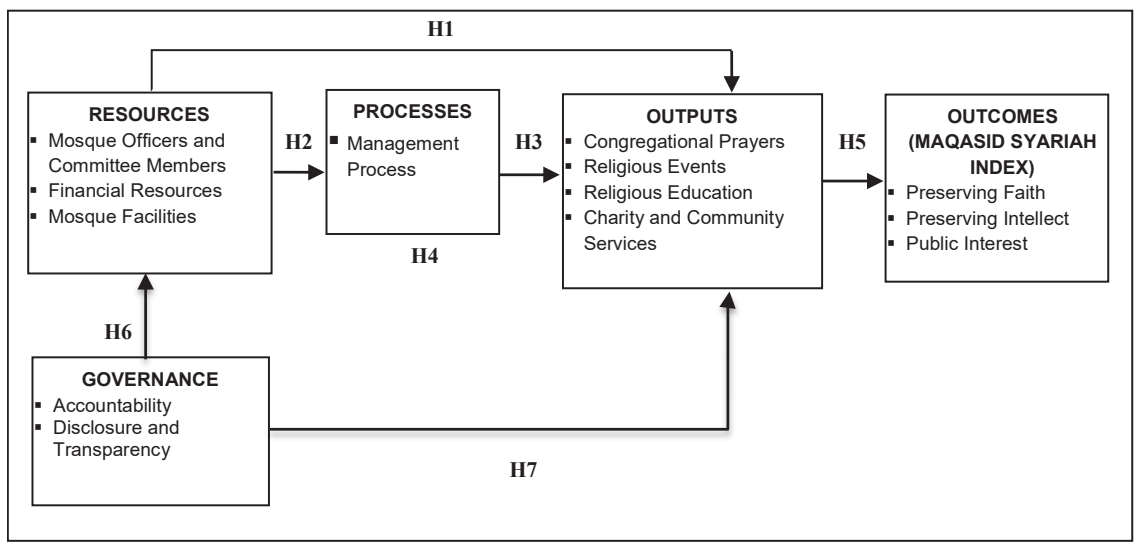

Figure 1: The Conceptual Framework

RBV is built upon the theory that a firm's success is largely determined by the resources it owns and controls (Wernerfelt, 1984). However, not all type of resources contributed to superior outputs. Only those resources that are valuable, rare, inimitable, and non-substitutable (VRIN) are capable of generating and sustaining competitive advantage which then, results in superior outputs (Lin and Wu. 2014). Competing firms which do not possess VRIN resources will have difficulty in duplicating value-creating strategies by superior firms which position the latter in the forefront (Armstrong and Shimizu, 2007; Ray et al., 2004). This does not mean that non-VRIN or ordinary resources are not important to a firm's outputs. Ordinary resources are neutral in terms of performance because their expected productivity is equal to costs (Warnier et al., 2013). Also, these resources are relatively available to most firms and are generally required for the firms to function properly as they are often used in production processes. While their presence does not generally create a competitive advantage, their absence could incur additional costs for the firm and destroy value (Warnier et al., 2013). It is worth noting that the VRIN Model and more generally the principles of RBV, only applies to firms seeking to establish a sustainable competitive 
advantage. For firms which are satisfied with their competitive position, the RBV seems to be of little use (Kraaijenbrink et al, 2010).

There are several empirical studies examining the measurement of resources and their effects on outputs (Hitt et al., 2001; Roberts and Dowling, 2002; Hansen et al., 2004; Karami et al, 2004; Lin and Wu, 2014). These researchers found that the positive effects on firm outputs are generally supportive of the RBV. However, not all studies agreed with the RBV theory such as those undertaken by Armstrong and Shimizu (2007); Newbert (2007); and Kraaijenbrink et al., (2010) which have extensively criticised the RBV for its weaknesses. Newbert (2007) performed a semiquantitative analysis on a sample of RBV-grounded empirical articles which was further analysed in order to assess the actual level of empirical support for the RBV with regard to the resources-outputs linkage. After the application of relevance criteria, he was left with 55 studies from which he generated the following conclusion. He found that only $53 \%$ of the papers examined offered positive support for the link between resources and outputs. A substantial portion of the samples yielded insignificant results which indicated no relationship between resources and outputs. Armstrong and Shimizu (2007) adopted a similar approach in reviewing empirical studies of the RBV and examined methodological issues and new directions that will help clarify the value and boundaries of the RBV Theory. Through their comprehensive review of the research design and operationalisation of resource-based constructs used in 125 empirical studies, they found that some resources did contribute to firm competitive advantage and outputs positively, whereas some other resources had negative effects on outputs.

Although the above studies were based on for-profit organisations, the arguments are also relevant to NPOs such as mosques which have their own resources that could influence outputs (Sillanpaa, 2011). However, in the past, studies on the RBV based on NPOs have been rather neglected. Addressing the gap in the literature, this study proposed to test the relationship between resources and outputs for NPOs such as mosques. VRIN resources which are also termed as 'strategic resources' are superior in nature and are normally categorised under intangible resources that involves skills or capabilities (Hall, 1992). Hence, mosques which have experienced and skilful management teams are expected to perform better than mosques with a less capable management. Beside intangible resources, 
ordinary resources such as financial funds and mosque facilities could also contribute to better outputs (Warnier et al,, 2013). Based on these arguments, this study developed the first hypothesis to test resources in general:

H1: There is a significant relationship between the resources and outputs in mosques.

The RBV suggests that a firm must possess strategic resources which are valuable and rare in order to create a competitive advantage. The Theory also made an implicit assumption that the managers are limited in their ability to manipulate all the attributes and characteristics of firms. Hence, it is this limitation that makes some firm resources difficult to imitate and non-substitutable. And it is this inability of managers that was seen as a limitation and consequently, became the source of heavy criticisms for the RBV. The definitions of resources are all inclusive according to the RBV (Priem and Butler, 2001). The RBV does not recognize differences between resources as inputs and resources that enable the organisation of such inputs, which are termed as capabilities (Kraaijenbrink et al., 2010). This problem is particularly apparent when one considers the notion of a 'dynamic capability' which is defined as 'the firm's processes that use resources - specifically the processes to integrate, reconfigure, gain and release resources - to match and even create market change" (Eisenhardt and Martin, 2000, p. 1107) which is also deemed as resources. As a result, the demarcation lines between resources, capabilities and processes becomes quite vague. To arrive at a better-determined concept of resources and capabilities, it is therefore useful to explicitly distinguish resources and capabilities on the one hand, and processes as a firm's enabler on the other hand (Hodgson, 2008).

Furthermore, of late, scholars have questioned the predictive power of the RBV without the element of processes as a catalyst for a firm's competitive advantage and outputs (Sirmon and Hitt, 2003; Sirmon et al., 2007;). The argument is that the RBV alone is not enough to explain firm competitive advantage unless the processes of transforming firm resources are taken into account (Sirmon et al., 2007). Other studies have also suggested that there is a direct relationship between all types of resources and processes (Buckmaster, 1999; Sillanpaa, 2011). Sillanpaa (2011) presented a model of performance for welfare service organisations, including the 
relationship between resources and processes. In the model, all types of resources including employees, management, financial resources, facilities, and client characteristics are expected to influence processes which include management processes, organisational structure and quality of working life. Based on the above arguments, this study hypothesized that there exists a positive relationship between resources and processes. This led to the development of the second hypothesis:

H2: There is a significant relationship between the resources and processes in mosques.

The Resource Management Process Model by Sirmon et al., (2007) not only requires managers be able to acquire, accumulate and divest (if necessary) resources to achieve the most effective resource portfolio but also requires the managers to develop the skills necessary to bundle resources for creating effective capabilities. Managers should also have the leveraging skills that include the ability to design appropriate strategies (mobilizing capabilities) necessary to identify and exploit opportunities in the market. Although the RVB suggests that resources influence outputs, based on research conducted by Sirmon et al. (2007) this influence is not only attained by merely possessing resources, but it requires specific processes leading to the structuring of a firm's portfolio of resources, resource bundling and resource leveraging to realize superior outputs. Moxham and Boaden (2007) who reviewed several studies on NPOs highlighted the work by Poister (2003) who developed a generic programme logic model based on input-process-output framework which was designed so that organisations could articulate worthwhile performance results and provide evidence that the organisations' processes are producing outputs. Other studies on NPOs also suggested that there is a positive relationship between processes and outputs (Sillanpaa, 2011; Buckmaster, 1999). According to Lee and Nowell (2015), some NPOs have constructed effective internal processes (that deliver value to customers and reduce operating expenses) and structures to use the resources efficiently and effectively toward the achievement of the organisation's objectives. Hence, processes play a vital role in transforming resources into outputs.

Following the above arguments, the management of mosques comprising mosque officers and committee members will have to play a 
more proactive role and show greater commitment in order to achieve better outputs (Alim and Abdullah, 2010). Through processes, the managers must be able to organize and manipulate all the resources at their disposal and to transform these resources into outputs in the form of religious activities and programs. Managers must be able to identify the critical resources controlled by the mosque and also, increase the likelihood of these resources being used to gain better outputs. Based on the Resource Management Process Model (Sirmon et al., 2007) as described above, this study posited the question if the relationship between processes and outputs is positive, which led to the development of the third hypothesis:

H3: There is a significant relationship between the processes and outputs in mosques.

Tangible resources such as mosques officers, committee members, financial funds and mosques facilities dedicated to religious activities and programs are valuable resources that can influence outputs. Processes refer to the organisation of work activities that transform resources (people, equipment, materials, facilities, information, etc.) into outputs such as products or services. Outputs are the direct products of the religious activities and programs; they are measured in financial or non-financial units (Sillanpaa, 2011; Packard, 2010).

The RBV suggests that resources directly influence outputs. However, based on the research conducted by Sirmon et al., (2007), this influence did not accrue from the possession of resources but rather, it involved specific management processes in structuring a firm's portfolio of resources, resource bundling and resource leveraging to realize competitive advantage. Although past studies focus on the direct relationship between resources and outputs (Barney and Clark, 2007; Peteraf, 1993), recent studies have found that the mediating role of processes had a significant influence on outputs (Sirmon et al., 2010; Hansen et al., 2004). Another recent study by Lin and Wu (2014) showed that dynamic capabilities (integration, learning and reconfiguration) can mediate a firms VRIN resources to improve outputs. They also found that non-VRIN resources had an insignificant mediating effect based on a study of top 1,000 Taiwanese companies. Similar suggestions are applicable to NPOs in that there are several factors that may explain the relationship between resources and outputs (Sillanpaa, 2011). However, the VRIN 
criteria are not always necessary and not always sufficient to explain a firm's strategic competitive advantage as stated above. The RBV does not sufficiently consider the synergy within resource bundles as a source of strategic competitive advantage (Kraaijenbrink et al., 2010). Furthermore, the definitions of resources are all inclusive. The RBV does not recognise differences between resources as inputs and resources that enable the organisation of such inputs. There is no recognition of how different types of resources may contribute to outputs in a different manner (Kraaijenbrink et al., 2010).

There are two schools of thought with regard to the relationship between resources, processes and outputs. The RBV claims that there is a direct positive relationship between strategic resources and outputs (Barney and Clark, 2007), whereas the performance measurement design based on the input- process-output framework stipulates those processes play a full mediating role between all types of resources and outputs (Sillanpaa, 2011; Buckmaster, 1999). The latter view was supported by an early study by Mahoney (1995) which suggested that RBV alone is not enough to explain firm superior outputs unless the management process of transforming firm resources is taken into account. A recent view on the mediating role of processes between resources and outputs is based on a study of NPOs which was put forward by Lee and Nowell (2015). They concluded that processes played a vital role in transforming resources into outputs. According to Barron and Kenny (1986), a mediator establishes "how" or "why" one variable predicts or causes an outcome variable. To be more specific, a mediator is defined as a variable that explains the relation between a predictor and an outcome (Frazier et al., 2004). Hence, in this study, processes played the mediating role that explained the relationship between all types of resources and outputs respectively. As a result, the following fourth hypothesis was proposed:

H4: Processes mediated the influence of resources on the outputs in mosques.

In a profit-making organisation, the main objective of the company is to make a profit. The profit obtained is shown in the company's income statement and statement of financial position. From these financial statements, the performance of these organisations can be analysed and 
examined to ascertain whether the organisation has achieved its intended objectives (Neely et al., 2005). Past studies on NPOs by Sillanpaa (2011) and Buckmaster (1999) also suggested that outputs influence outcomes positively. Sillanpaa (2011) measured outputs based on the number of services provided by the welfare service organisations. Outcomes which represented the organisations' objectives were measured proximately by changes in clients' health, wellbeing, and quality of life; customer/ stakeholder satisfaction; and employee satisfaction.

Unlike profit-making organisations, mosques are NPOs serving the religious needs of Muslims. Hence, the traditional performance measurement which uses financial measures as its yardstick may not be suitable to nonprofit religious organisations such as mosques which have different sets of objectives compared to profit-making organisations. In this study, the objectives of the mosques were based on the Maqasid al-Syariah that conforms to the three objectives of Islamic law namely, preserving of faith (Maqasid 1), preserving of intellect (Maqasid 2) and public interest (Maqasid 3). Performance measurement which measures outputs undertaken by an organisation, is also a process that ascertains whether the organisation has achieved its objectives in the form of outcomes (Folan et al., 2007; Wholey, 1996). Hence, in this study, outcomes measure was replaced with the Maqasid Syariah Index as a more suitable measure of mosque performance. Since there is a lack of literature on the relationship between outputs and the Maqasid Syariah Index, this study used the work of Mohammed et al., (2008) based on their Islamic Bank Model which examined the relationship between outputs and outcomes from the Maqasid al-Syariah perspective.

Thus, this study posited that there is a positive relationship between outputs and the Maqasid Syariah Index as a measure of the mosques' objectives. This led to the development of the fifth hypothesis:

H5: The outputs of mosques have a significant influence on the Maqasid Syariah Index.

Governance of resources, from the Islamic perspective, applies to those in charge of economic resources who are obligated to present an account of the execution of their stewardship, irrespective of the resources in question are those of public, for-profit or NPOs. Therefore, those who are entrusted 
with the utilisation of these resources will be held accountable for their actions or inactions. Governance can be defined as the manner in which power is exercised in the management of an organisation. This reflects the definition put forth by the Finance Committee on Corporate Governance (1999) that corporate governance involves "the process and structure used to direct and manage the business affairs of the company towards enhancing business prosperity and corporate accountability with the ultimate objective of realising long-term shareholders' value, whilst taking into account the interests of other stakeholders". One of the key challenges of managing mosques today is to resolve governance issues such as lack of accountability (Mohamed et al., 2014) and disclosure practices (Zainon et al., 2014) in mosques. Studies have found that lack of transparency and accountability in the NPOs tended to increase opportunities for fraud (Dellaportas et al., 2011; Sulaiman et al., 2007). Hence, it can be argued that increasing governance mechanisms for mosques through accountability and disclosure practices, should theoretically, positively affect resources and outputs. In fact, there is considerable evidence for the link between good governance and better outputs (Abu-Tapanjeh, 2009; Herman and Renz, 2000) especially for corporate organisations. However, fewer studies have involved NPOs.

On the other hand, efficiency is a term used to measure how well an organisation utilises its resources through the management processes to achieve its specific objectives (Neely et al., 2005). In the context of this study, efficiency refered to how well the mosques used their resources (e.g. mosques officers and committee members, financial resources, and mosques facilities) to produce outputs which met their objectives of preserving of faith, preserving of intellect and public interest. Also, as explained earlier, through processes, i.e. the management process plays a mediating role between resources and outputs according to performance measurement perspectives. However, the role of governance has not been fully explored from the perspective of a performance measurement framework.

This may be attributed to less attention given to the relationship between resources and processes on the one hand, and the relationship between processes and outputs on the other hand. The widely accepted view in most studies is centred on processes which play the role of mediator in the performance measurement framework including NPOs (Sillanpaa, 2011; Lee and Nowell, 2015). 
However, Cornforth (2001) used to examine the relationships between board inputs, board processes, and outputs in 737 non-profit organisations in United Kingdom and revealed mixed findings. Although the relationship between inputs and processes was generally found to be significant, there were certain factors in processes which caused this relationship to be weak. The same result was found in the relationship between processes and outputs. Another study by van Ees et al., (2008) found that 'trust' moderated the effect of board processes on outputs indicating a possible role of a moderator between the relation of processes and outputs. Drawing from the findings of these studies, there could be a possibility that there may be other factor(s) that could have some influence on the relationship between resources and processes; processes and outputs in a performance measurement framework, such as a moderator or other independent variables such as governance. As not many studies have explored the relationship between governance and resources as well as governance and outputs for NPOs, this study proposed to undertake the following sixth and seventh hypotheses as new area of research:

H6: Governance has a direct influence on resources in mosques.

H7: Governance has a direct influence on outputs in mosques.

\section{RESEARCH METHOD}

The population was selected from three differing categories of mosques in Malaysia, ie. the state, district and qariah mosques, to form the sample for this research. The smaller type of mosques known as surau was not included. Currently, Malaysia has over 6,000 mosques (JAKIM), of which ninety two percent (92\%) of mosques in each Malaysian state are categorized as qariah mosques, while the remaining (8\%) comprises of state mosques and district mosques. Initially, the stratified random sampling method was employed to separate the mosques into three homogeneous subgroups (strata) based on the types of mosques. A simple random sample was subsequently identified from each subgroup or stratum (Malim and Abdul Halim, 2011). It is important that the samples are representative of the whole population, and that the three major subcategories comprising qariah mosques (strata 1 ), district mosques (strata 2), and the minority subcategory which is the 
state mosques (strata 3) were included (Abd Rahman et al., 2016). The survey encompassed all states in Malaysia including East Malaysia; Sabah ans Sarawak. To cater to the population size and the vast geographical area involved, the cost-effective self-administered questionnaire was used as the primary data collection method (Cooper and Schindler, 2008). The booklet questionnaires were sent to 800 mosques that were chosen at random from around the nation. These were also accompanied with postage paid envelopes to help respondents return the questionnaires easily. Only 224 questionnaires were returned, out of which 210 (26.3\%) were usable whilst another 14 were incomplete hence unusable. Notably, the accepted response rate of $20 \%$ suggested by past literature was met (Jobber et al., 1991).

Various instruments as well as the literature were sourced to develop the questionnaire, specifically the ones used to measure resources, processes, outputs and governance for performance measurement. The questionnaire items were presented using the Likert scale, from 1 (strongly disagree) to 5 (strongly agree) and 1 (seldom) to 5 (always). Additionally, a dichotomous scale item offering two mutually exclusive responses, ie. "yes" or "no", was employed. After conducting a pre-test and pilot test, the total number of 103 items were used in the final instrument. To assess if the variables formed a reliable scale, Construct Reliability (CR) was computed using Structural Equation Modeling or SEM. The CR for the variables examined were above 0.70 , which indicated that the items in the variables were reliable as they formed a scale that had good internal consistency (Fornell and Larcker, 1981). Overall, the values as shown in Table 1 confirmed that the data collected was appropriate data that can be used for inferential statistics. The results of the standard deviations and skewness values did not suggest problems with the assumptions of normality. Confirmatory Factor Analysis (CFA) was employed to provide a confirmatory test of the measurement scale. Only those items with loading above 0.50 and the Average Variance Extracted (AVE) equal and above 0.50 were maintained. The final items remained at 79 items after 24 items were deleted. 
Table 1: Construct Reliability, AVE and Kolmogorov-Smirnov Test

\begin{tabular}{|c|c|c|c|c|c|c|c|}
\hline \multirow[t]{2}{*}{ Variable } & \multirow{2}{*}{$\begin{array}{l}\text { Construct } \\
\text { Reliability }\end{array}$} & \multirow[t]{2}{*}{ AVE } & \multirow[t]{2}{*}{ Mean } & \multirow{2}{*}{$\begin{array}{l}\text { Standard } \\
\text { Deviation }\end{array}$} & \multicolumn{2}{|c|}{$\begin{array}{l}\text { Kolmogorov- } \\
\text { Smirnov Test }\end{array}$} & \multirow[t]{2}{*}{ Skewness } \\
\hline & & & & & Statistic & Sig. & \\
\hline Resources & 0.92 & 0.50 & 4.34 & 0.34 & 0.08 & 0.002 & -0.14 \\
\hline Processes & 0.93 & 0.50 & 4.05 & 0.43 & 0.03 & 0.200 & -0.23 \\
\hline Outputs & 0.94 & 0.52 & 3.46 & 0.81 & 0.05 & 0.200 & -0.14 \\
\hline Governance & 0.88 & 0.54 & 3.04 & 1.11 & 0.08 & 0.003 & 0.17 \\
\hline
\end{tabular}

The SEM test was next performed to assess measurement model fit in which the indices of the measurement model must achieve the minimum acceptable level values. The results showed overall model fit for the variables tested on resources, processes, outputs, and governance which fall within the recommended values for $\chi^{2} / \mathrm{df}(\leq 5.00)$, GFI $(\geq 0.90)$, NFI $(\geq 0.90)$ and RMSEA $(\leq 0.08)$ respectively. Table 2 shows the fit indices of the measurement model.

Table 2: Fit Indices of the Measurement Model

\begin{tabular}{lcccccc}
\hline Variables & $\mathbf{X}^{2}$ & $\mathbf{d f}$ & $\mathbf{X}^{2} / \mathbf{d f}$ & GFI & NFI & RMSEA \\
Resources & 85.78 & 50 & 1.72 & 0.94 & 0.91 & 0.06 \\
Processes & 83.45 & 60 & 1.39 & 0.95 & 0.91 & 0.04 \\
Outputs & 119.24 & 84 & 1.42 & 0.93 & 0.93 & 0.05 \\
Governance & 20.75 & 8 & 2.59 & 0.97 & 0.95 & 0.08 \\
\hline
\end{tabular}

\section{FINDINGS AND DISCUSSION}

The conceptual framework for this study was tested using the SEM based on the full structural framework. Figure 2 provides evidence on the performance measurement framework of mosques, further emphasising the viability of the structural framework. The framework had a good fit with $\chi 2=179.00$, $\mathrm{df}=94, \mathrm{p}=0.0001, \mathrm{GFI}=0.91, \mathrm{NFI}=0.90, \mathrm{RMSEA}=0.07$. The $\chi 2 / \mathrm{df}$ value of 1.90 which is less than 5 together with the rest of the goodness-of-fit indices which met the recommended values level, indicating that a good fit model was achieved. Table 3 presents the results from the SEM as well. Although, there was a positive link between resources and outputs, it was not significant at $\mathrm{P}=0.40$ and thus, hypothesis $\mathrm{H} 1$ was not supported. On the other hand, the regression weights indicated that resources were significantly and positively 
related to processes; and processes were positively related to outputs. The hypotheses $\mathrm{H} 2$ and $\mathrm{H} 3$ were supported. These results augmented the works of Sillanpaa (2011) and Noor et al. (2012).

H4 was strongly supported according to results obtained through the Sobel Test Calculator for the significance of mediation available from the website http://danielsoper.com. The Sobel test on two-tailed probability provided a significant value of 0.005 . The results agreed with Lin et al., (2014), and Sirmon et al., (2007). The model paths of the indirect effects were found to be significant $(\mathrm{p}<0.01)$ whereas the direct effect of resources on outputs (H1) was not significant, thus indicating a full mediation model. According to Hair et al. (2010), if the direct effect is not statistically significant after a predictor is included, then it can be concluded that the full mediation is supported for the framework. The full structural framework with resources, processes, outputs and the three objectives, together with their respective dimensions are illustrated below.

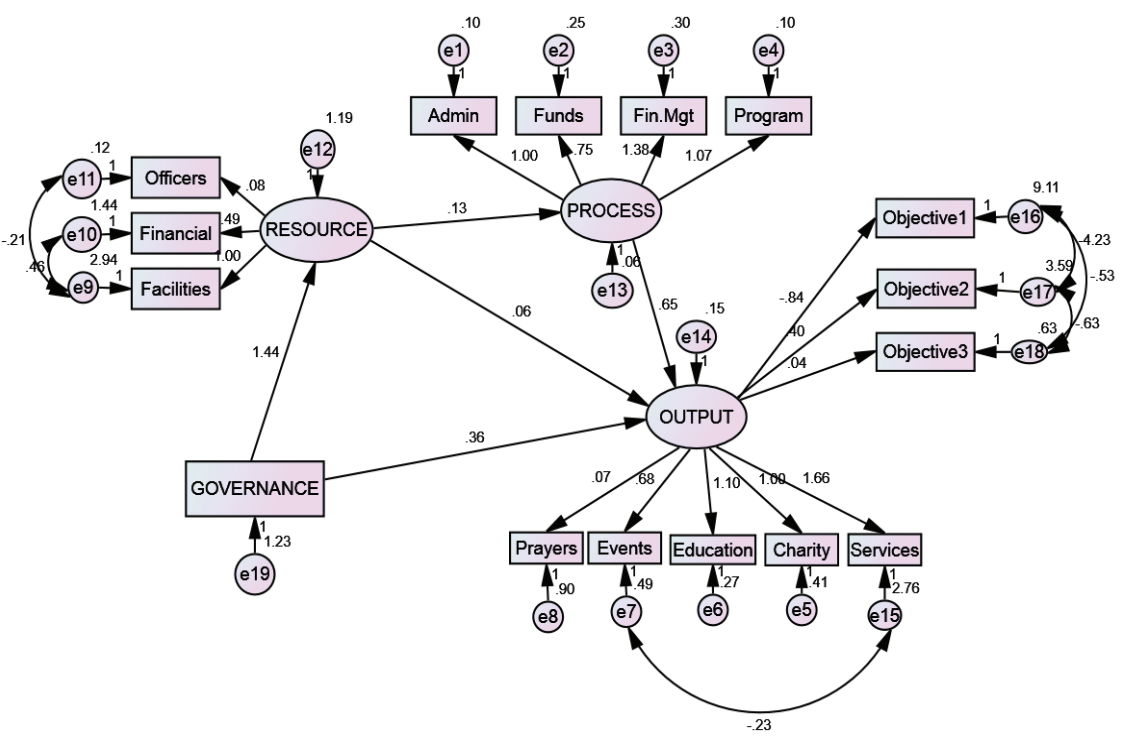

Figure 2: Performance Measurement Framework

The other path coefficients that needed to be addressed was the relationship between outputs and the three objectives. The regression coefficient for the path estimates between outputs and objective 1 was 
negative 0.84 and was significant at $p<0.01$. This indicated that an increase in the outputs by 1 , resulted in a proportionate decrease of 0.84 for Objective 1 which represented the performance indicators of congregational prayers and religious events. On the other hand, the estimate of regression coefficient for outputs to Objective 2 was a positive 0.40 which indicated that when outputs went up by 1 , Objective 2 increased by 0.40 times. The path coefficient was significant at $p<0.05$. The relationship can be interpreted as that any increase in the outputs resulted in an increase in Objective 2 which signified the performance indicator for religious education. Although Objective 3 was not significant, the regression coefficient of 0.04 indicated a small but positive association between outputs and the Objective 3 which represented the performance indicator for charity and community services. The overall objective of Maqasid Syariah Index which is the summation of the three objectives was negatively significant with a path coefficient of -0.40 . This indicated that an increase in the outputs by 1 , resulted in a proportionate decrease of 0.40 for the Maqasid Syariah Index. Hence, hypothesis H5 was also supported.

Finally, the results showed that governance had direct influence on resources and outputs respectively (Figure 2 and Table 3 ). The direct relationship between governance and resources was positively significant at $\mathrm{p}<0.01$, and thus hypothesis H6 was supported. Governance which has a direct influence on resources was in line with the Resource Dependency Theory (Arregle et al, 2012) where mosque committee members are able to provide linkages for example, with major financial contributors and they also bring into the mosques different kinds of expertise that are beneficial to organisational performance. Similarly, the direct relationship between governance and outputs was significant at $\mathrm{p}<0.01$, and thus hypothesis $\mathrm{H} 7$ was supported. This positive relationship between governance and outputs was in line with the major theories of corporate governance whereby the governance mechanism such as effective monitoring and accountability by the board (Abu-Tapanjeh, 2009), board and management interest in the organisation (Zainal Abidin et al., 2009), can directly influence organisational performance. 
Table 3: Regression Weights of the Performance Measurement Framework

\begin{tabular}{lcccc}
\hline \multicolumn{1}{c}{ Path } & Estimate & $\begin{array}{c}\text { Standard } \\
\text { Error }\end{array}$ & $\begin{array}{c}\text { Critical } \\
\text { Ratio }\end{array}$ & P \\
\hline Outputs $\leftarrow$ Resources & 0.06 & 0.07 & 0.84 & 0.40 \\
Processes $\leftarrow$ Resources & 0.13 & 0.02 & 7.41 & $* *$ \\
Outputs $\leftarrow$ Processes & 0.65 & 0.23 & 2.89 & $* *$ \\
Outputs $\leftarrow$ Governance & 0.36 & 0.09 & 4.13 & $* *$ \\
Resources $\leftarrow$ Governance & 1.44 & 0.13 & 11.54 & $* *$ \\
Objective $1 \leftarrow$ Outputs & -0.84 & 0.29 & -2.88 & $* *$ \\
Objective $2 \leftarrow$ Outputs & 0.40 & 0.18 & 2.21 & $*$ \\
Objective $3 \leftarrow$ Outputs & 0.04 & 0.08 & 0.56 & 0.57 \\
Maqasid $\leftarrow$ Outputs & -0.40 & 0.15 & -2.58 & $* *$ \\
\hline Note: ${ }^{*}<0.05,{ }^{* *} p<0.01$ & & & &
\end{tabular}

\section{CONCLUSION}

In conclusion, based on the SEM analysis the conceptual framework showed a good model fit and the results supported the theories. Thus, the conceptual framework is viable for measuring mosque performance. Three main findings were obtained from this research. Firstly, the finding from this study suggest that processes play a very important role in mediating the influence of resources on outputs and thus are consistent with past studies. Therefore, it is imperative for the management of mosques should comprise of top-notch managers who are skilful and capable in exploiting existing resources to the full if performance of mosques are given top priority. Secondly, the Maqasid Syariah Index proved to be negatively significant indicating that as outputs increase, the objectives of the mosques generally diminish. This inverse relationship indicated that there is a reduction in the mosques performance as outputs increased. The negative significant of Maqasid Syariah Index showed that mosques are not able to meet their objectives with increased outputs, and thus the effectiveness of the religious activities and programs can be called into question. Thirdly, governance directly affected resources and outputs in mosques. The governance mechanisms through the application of accountability, disclosure and transparency dimensions had direct effects on mosque resources. This could be the case since it is possible that with the presence of governance mechanisms, mosques officers and committee members will be more responsible, as well as accountable and transparent in utilising resources. Proper resource utilisation will allow mosques to 
organise more religious activities and projects which lead to higher outputs. Fourth, at a significance level of $p=0.01$, there was a significance relationship between resources and outputs, simply meaning that the higher the mosques resources, the more the outputs generated. However, in the full structural framework, this hypothesis was not supported since the p-value was not significant at 0.45 . The overriding factors sich as the mediation role of processes reduced the direct influence of resources on outputs, causing the later to be insignificant. Thus, the application of RBV cannot be upheld, since this study wasunable to identify any strategic resource with certainty, which can significantly contribute to mosque performance.

In sum, the results of this study will provide value to mosque stakeholders, specifically those who are direct recipients of mosque operations and activities, such as religious authorities and the community at large. This study is not without limitations. Firstly, existing frameworks on performance measurement of mosques are lacking for comparison and thus, limitations exists because it covers the performance measurement frameworks based on for-profit and other NPOs. The underlying theory of performance measurement which examines the relationships on the horizontal flow of resources, processes, outputs and outcome measures of mosques were also adopted from studies on NPOs. Secondly, the total usable data of 210 used in this study is also a minimal amount of sample data required to be able to run on SPSS AMOS with accurate results. Thirdly, the questionnaire was lengthy as it consisted of 103 items and a few respondents expressed concerns about its length. This lengthy questionnaire was due to the adaptation and combination of many instruments from prior studies.

\section{FUTURE RESEARCH}

Future research may use the performance measurement used in this study to measure performance of other NPOs such as zakat institutions and wakaf. In addition, future research may be extended to other Islamic countries. The present study has not tested the association between governance and process thus, providing an avenue for further research. 


\section{REFERENCES}

Abd Rahman, M. F., Mastuki, N. \& Syed Yusof, S. N. (2015). Performance Measurement Model of Mosques. Procedia Economics and Finance, 31, 26-35.

Abd Rahman, M. F., Mastuki, N. \& Syed Yusof, S. N. (2016). The performance measurement model of mosques in Malaysia based on the Maqasid Shariah Index approach. Management and Accounting Review (MAR), 15(1), 131-147.

Abdullah, M. Y. M., \& Aini, Z. H. (2017). The Efficiency Model of Mosque Management for the Indigenous Community in Selangor. Jurnal Hal Ehwal Islam Dan Warisan Selangor, 1-9.

Abu-Tapanjeh, A. M. (2009). Corporate governance from the Islamic perspective: A comparative analysis with OECD principles. Critical Perspectives on Accounting, 20(5), 556-567.

Afifuddin, H. B., \& A. K. Siti-Nabiha (2010). Towards Good Accountability: The Role of Accounting in Islamic Religious Organisations. World Academy of Science, Engineering and Technology, 42, 1119-1125.

Alim, A. P., \& Abdullah, S. R. (2010). Audit Pengurusan Masjid: Kajian di Daerah Pasir Puteh, Kelantan. Retrieved 22nd May 2013 from http:// eprints.utm.my.

Amit, R., \& Schoemaker, P. J. (1993). Strategic assets and organizational rent. Strategic management journal, 14(1), 33-46.

Armstrong, C. E., \& Shimizu, K., (2007). A Review of Approaches to Empirical Research on the Resource-Based View of the Firm. Journal of management, 33(6), 959-986.

Arregle, J. L., Naldi, L., Nordqvist, M., \& Hitt, M. A. (2012). Internationalization of family-controlled firms: A study of the effects of external involvement in governance. Entrepreneurship Theory and Practice. 36 (6), 1115-1143. 
Arshad, R., Zain, N. M., Urus, S. T., \& Chakir, A. (2018). Modelling maqasid waqf performance measures in waqf institutions. Global Journal AlThaqafah, 8(1), 157-170.

Barney, J. (1991). Firm resources and sustained competitive advantage. Journal of management, 17(1), 99-120.

Barney, J. B., \& Clark, D. N. (2007). Resource-based theory: Creating and sustaining competitive advantage. Oxford: Oxford University Press.

Baron, R. M., \& Kenny, D. A. (1986). The moderator-mediator variable distinction in social psychological research: Conceptual, strategic, and statistical considerations. Journal of personality and social psychology, 51(6), 1173- 1182.

Borhan, J. T., Husin, M. Y. M., Muhammad, F., \& Fauzi, M. Abu@ Hussin. (2011). Membentuk Usahawan Muslim: Peranan Dana Masjid.

Buckmaster, N. (1999). Associations between outcome measurement, accountability and learning for non-profit organisations. International Journal of Public Sector Management, 12(2), 186-197.

Burvill, S. M., Jones-Evans, D., \& Rowlands, H. (2018). Reconceptualising the principles of Penrose's (1959) theory and the resource based view of the firm. Journal of Small Business and Enterprise Development, 25(6), 930-959.

Cooper, D.R. \& Schindler, P.S. (2008). Business research methods. International edition: McGraw-Hill.

Cornforth, C. (2001). What Makes Boards Effective? An examination of the relationships between board inputs, structures, processes and effectiveness in non-profit organisations. Corporate Governance: An International Review, 9(3), 217-227.

DeGroff, A., Schooley, M., Chapel, T., \& Poister, T. H. (2010). Challenges and strategies in applying performance measurement to federal public health programs. Evaluation and program planning, 33(4), 365-372. 
Dellaportas, S., Langton, J., \& West, B. (2011). Governance and accountability in Australian charitable organisations Perceptions from CFOs. International Journal of Accounting and Information Management, 20(3), 238-254.

Eisenhardt, K. M., \& Martin, J. A. (2000). Dynamic capabilities: what are they? Strategic Management Journal, 21(10-11), 1105-1121.

Finance Committee on Corporate Governance (1999). Report on Corporate Governance. Finance Committee on Corporate Governance, Kuala Lumpur.

Folan, P., Browne, J., \& Jagdev, H. (2007). Performance: Its meaning and content for today's business research. Computers in industry, 58(7), 605-620.

Frazier, P. A., Tix, A. P., \& Barron, K. E. (2004). Testing moderator and mediator effects in counselling psychology research. Journal of Counselling Psychology, 51(1), 115-134.

Fornell, C., \& Larcker, D. F. (1981). Evaluating structural equation models with unobservable variables and measurement error. Journal of Marketing Research, 18, 39-50.

Galbreath, J. (2005). Which resources matter the most to firm success? An exploratory study of resource-based theory. Technovation, 25(9), 979-987.

Hair, J. F., Black, W. C., Babin, B. J., \& Anderson, R. E. (2010). Multivariate data analysis (6th Ed.). Upper Saddle River, New Jersey, NJ: Pearson Education.

Hall, R. (1992). The strategic analysis of intangible resources. Strategic management journal, 13(2), 135-144.

Hansen, M. H., Perry, L. T., \& Reese, C. S. (2004). A Bayesian operationalization of the resource-based view. Strategic Management Journal, 25(13), 1279-1295. 
Herman, R. D., \& Renz, D. O. (2000). Board practices of especially effective and less effective local nonprofit organizations. The American Review of Public Administration, 30(2), 146-160.

Hitt, M. A., Bierman, L., Shimizu, K., \& Kochhar, R. (2001). Direct and moderating effects of human capital on strategy and performance in professional service firms: A resource-based perspective. Academy of Management journal, 44(1), 13-28.

Hodgson, G. M. (2008). The concept of a routine. The handbook of organizational routines, 15-29. Cheltenham, UK. Edward Elgar.

JAKIM (Jabatan Kemajuan Islam Malaysia). Direktori Masjid. Retrieved $29^{\text {th }}$ August 2012 from http://www.islamgrid.gov.my

Jobber, D., Mirza, H., \& Wee, K. H. (1991). Incentives and response rates to cross-national business surveys: a logit model analysis. Journal of International Business Studies (Fourth Quarter), 711-721.

Karami, A., Analoui, F., \& Cusworth, J. (2004). Strategic human resource manaement and resource-based approach: the evidence from the British manufacturing industry. Management Research News, 27(6), 50-68.

Kraaijenbrink, J., Spender, J. C., \& Groen, A. J. (2010). The resource-based view: a review and assessment of its critiques. Journal of management, 36(1), 349- 372 .

Lee, C. \& Nowell, B. (2015). A Framework for Assessing the Performance of Nonprofit Organizations. American Journal of Evaluation, 36(3), 299-319.

Lin, Y., \& Wu, L. Y. (2014). Exploring the role of dynamic capabilities in firm performance under the resource-based view framework. Journal of Business Research, 67(3), 407-413.

MAIS News (2012). Merdekakah pemilihan jawatankuasa masjid? Retrieved 17 October 2012 from http://www.mais.gov.my. 
Malim, M.R. and Abdul Halim, F (2011). Business Statistics. Kuala Lumpur: Oxford University Press.

Mohamed Adil, M. A., Mohd Sanusi, Z., Jaafar, N. A., Khalid, M. M., \& Abd Aziz, A. (2013). Financial management practices of mosques in Malaysia. GJAT, 3(1), 1- 7.

Mohamed, I. S., Ab Aziz, N. H., Masrek, M. N., \& Mohd Daud, N. (2014). Mosque fund management: issues on accountability and internal controls. Procedia - Social and Behavioral Sciences, 145 (2014), 189194.

Mohammed, M. O., Abdul Razak, D., \& Md Taib, F. (2008). The Performance Measures of Islamic Banking Based on the Maqasid Framework. Retrieved 3rd September 2012 from http://irep.iium.edu. my.

Mohd Asri, Z. A. (2007). Masjid kita kaku, tidak mesra pelanggan. Retrieved 29th August 2012 from http://drmaza.com.

Moxham, C., \& Boaden, R. (2007). The impact of performance measurement in the voluntary sector: Identification of contextual and processual factors. International Journal of Operations \& Production Management, 27(8), 826- 845.

Moxham, C. (2009). Performance measurement: Examining the applicability of the existing body of knowledge to nonprofit organisations. International Journal of Operations \& Production Management, 29(7), 740-763.

Mustari, M. I. \& Jasmi, K. A. (2008). Pengurusan berkualiti memacu kecemerlangan pengurusan masjid. Retrieved 5th October 2015 from http:// www.penerbit.utm.my

Nason, R. S., \& Wiklund, J. (2018). An assessment of resource-based theorizing on firm growth and suggestions for the future. Journal of Management, 44(1), 32-60. 
Neely, A., Gregory, M., \& Platts, K. (2005). Performance measurement system design: a literature review and research agenda. International Journal of Operations \& Production Management, 25(12), 1228-1263.

Noordin, N. H., Haron, S. N., \& Kassim, S. (2017). Developing a comprehensive performance measurement system for waqf institutions. International Journal of Social Economics, 44(7), 921-936.

Omer, S. (2010). Some lessons from Prophet Muhammad (SAW) in architecture: The Prophet's Mosque in Madinah. Intellectual Discourse, $18,115-140$.

Packard, T. (2010). Staff perceptions of variables affecting performance in human service organizations. Nonprofit and Voluntary Sector Quarterly, 39 (6), 971- 990.

Peteraf, M. A. (1993). The cornerstones of competitive advantage: A resource-based view. Strategic management journal, 14(3), 179-191.

Poister, T. H. (2003). Measuring performance in public and nonprofit organizations. Wiley, New York, NY.

Priem, R. L., \& Butler, J. E. (2001). Is the resource-based "view" a useful perspective for strategic management research? Academy of management review, 26(1), 22-40.

Quran (n.d.). The Meaning of the Holy Qur'an by Abdullah Yusuf 'Ali. Amana Corporation, Brentwood, MD.

Ray, G., Barney, J. B., \& Muhanna, W. A. (2004). Capabilities, business processes, and competitive advantage: Choosing the dependent variable in empirical tests of the resource-based view. Strategic management journal, 25(1), 23-37.

Roberts, P. W., \& Dowling, G. R. (2002). Corporate reputation and sustained superior financial performance. Strategic Management Journal, 23(12), 1077-1093. 
Said, J., Mohamed, A., Mohd Sanusi, Z., \& Syed Yusuf, S. N. (2013). Financial Management Practices in Religious Organizations: An Empirical Evidence of Mosque in Malaysia. International Business Research, 6 (7), 111-119.

Sanusi, Z. M., Johari, R. J., Said, J., \& Iskandar, T. (2015). The effects of internal control system, financial management and accountability of NPOs: the perspective of mosques in Malaysia. Procedia Economics and Finance, 28, 156-162.

Sillanpaa, V. (2011). Performance measurement in welfare services: a survey of Finnish organisations. Measuring Business Excellence, 15(4), 6270 .

Sirmon, D. G., Hitt, M. A., \& Ireland, R. D. (2007). Managing firm resources in dynamic environments to create value: Looking inside the black box. Academy of management review, 32(1), 273-292.

Sirmon, D. G., Hitt, M. A., \& Ireland, R. D. (2007). Managing firm resources in dynamic environments to create value: Looking inside the black box. Academy of management review, 32(1), 273-292.

Sulaiman, M., Siraj, S. A., \& Ibrahim, S. (2008). The internal control system in West Malaysia's state mosque. The American Journal of Islamic Social Sciences. 25(1), 63- 81.

Van Ees, H., van der Laan, G., \& Postma, T. J. (2008). Effective board behaviour in the Netherlands. European Management Journal, 26(2), 84-93.

Warnier, V., Weppe, X., \& Lecocq, X. (2013). Extending resource-based theory: Considering strategic, ordinary and junk resources. Management Decision, 51(7), 1359-1379.

Wernerfelt, B. (1984). A resource-based view of the firm. Strategic management journal, 5(2), 171-180. 
Wholey, J. S. (1996). Formative and summative evaluation: Related issues in performance measurement. American Journal of Evaluation, 17(2), 145-149.

Yasmin, S., \& Haniffa, R. (2017). Accountability and narrative disclosure by Muslim Charity Organisations in the UK. Journal of Islamic Accounting and Business Research, 8(1), 70-86.

Zainal Abidin, Z., Mustaffa Kamal, N., \& Jusoff, K. (2009). Board structure and corporate performance in Malaysia. International Journal of Economics and Finance, 1(1), 150- 164. 